\title{
Movement of Real Wage Rate and Labour Productivity in Manufacturing Sector in India: The Role of Contract Labour
}

\author{
Soumita Chakraborty
}

Department of Economics, Dev Samaj College for Women, Sector 45B, Chandigarh, India

Corresponding author: soumi_29@rediffmail.com

\begin{abstract}
The present study attempts to find out the relationship between real wage rate and labour productivity as well as the wage share and labour's terms of trade in the manufacturing sector in India at both aggregated and disaggregated levels, during the post reform years. The empirical analysis reveals that in the organized manufacturing industry the declining wage share neutralizes the effect of increasing labour productivity resulting in stagnant wage rate growth. This absence of a link between productivity and real wage may be largely due to lower bargaining power and structural problems, including high unemployment, low wages, growing contractualisation of labour force and the large share of the informal sector in the Indian manufacturing sector. To bring back the economy to a stable growth path, efficient policy efforts on the part of the government are necessary to link productivity with real wage growth.
\end{abstract}

Keywords: manufacturing sector, labour productivity, real wage rate, wage share, labour's terms of trade, bargaining power, contract labour, wage policy

The micro economic theory of labour market states that under conditions of perfect competition, every worker with same skill and efficiency in a given category will receive a wage equal to the value of the marginal product of that type of labour. Thus, in the short run, profit maximising firm goes on employing labour until the real wage rate equals the value of marginal product of the labour, assuming factor and product markets perfectly competitive. Quite important, in the short run, capital tends to remain fixed, making the output being sensitive only to the labour. This assumption, however, is not realistic, because quantities of other factors too can be increased, though this may not happen in the short run.

To allow this fact, the economists make use of the term "marginal net product of labour" instead of "marginal product of labour". The value of marginal net product of labour may be defined as being the value of the amount by which output would be increased by employing one more worker, less the addition to the cost of the other factors caused by increasing the quantities of other factors. So, the rationality that is applicable to the short run is unlikely to emerge as a profit maximising conditions when both the capital and labour happen to be variable in the long run. Drawing cues from micro economic theory of production in the long run, the profit maximising employment of labour leads to wage is being determined by capital- labour ratio. In the long run, the most direct route by which labour productivity affects living standards is through real wages, that is, wages adjusted for the cost of living. Economic theory holds that at the aggregate level the growth of real wages is determined by labour productivity growth, a relationship mediated by the labour's share of output and labour's terms of trade (the price of output produced by workers relative to the cost of living). Productivity growth provides the basis for rising living standards. Increases in labor productivity - the most commonly used productivity measure-reflect investments in capital equipment and information technology, and the hiring of more highly skilled workers. Employers' ability to raise wages and other compensation is tied to increase in labor productivity (Fleck et al. 2011). 
Hence, if productivity is higher in a whole economy, the quantity of goods and services produced and consumed will increase, meaning all workers in an economy will enjoy better standard of living (Cashell, 2004).

The purpose of our study is to find out whether the labour productivity growth in organized manufacturing sector in India is successful in stimulating the living standard of workers. The objective of this study is to examine the relationship between labour productivity growth and real wage rate in organized manufacturing sector in India during the post reform years i.e. 1991 to 2010. In this context we will also attempt to find out the role of other factors influencing the wage rate in manufacturing sector in India at both aggregated and disaggregated levels during the study period. This work will examine the effect of productivity, and other influential components like output prices and annual hours worked per worker (hours to employment ratio) on total annual compensation per worker at the national level. In this context the paper also studies the role of contractual labour in the productive labour force and wage differential in Indian manufacturing sector during the post reform years.

The rest of the paper is organised as follows. In section 2, we briefly discuss the varied and diverse literature associated with the labour productivity and wage rate and other related variables. Section 3 derives the methodological framework for analysing the factors influencing the real wage rate following micro economic theory. In section 4, we present the coverage and analysis of the data collected for the purpose of our study. Section 5 presents and discusses the estimate and behaviour of the real wage rate and related variables in the manufacturing sector in India during the study period. Section 6 concludes the paper.

\section{SURVEY OF SELECTED LITERATURE}

The most direct mechanism by which labour productivity affects living standards is through real wages, that is, wages adjusted to reflect the cost of living. A recent study based on Canada and OECD countries (Sharpe, Arsenault, and Harrison; 2008) reveals that between 1980 and 2005, the median real earnings of Canadians workers stagnated, while labour productivity rose 37 per cent. According to this report four factors namely, rising earning inequalities; falling terms of trade for labour; a decrease in labour's share of GDP; and measurement issues force real wages stagnant while productivity rises. This report also explores the relationship between labour productivity and real wages by province and by sector, as well as in the United States and in other high-income countries. Using average annual macro-data for the period 2002-2013, for Poland and other 5 new EU members: Estonia, Hungary, Slovak, Czech Republic and Slovenia (Nikulin, 2015) determines the extent to which relative labour productivity and relative unemployment rate changes affect relative wage. It is found out that the trajectory of wage, productivity and unemployment rate development in new EU member countries is diversified. The study confirms a strong relationship between wage and productivity ratio changes in Poland compared to Czech Republic, Estonia and Hungary.

But correlations between wage and unemployment rate ratios are of smaller significance in almost all the countries. Another study carried out in Turkish manufacturing industry (Yildirim, 2015) for the period of 1988 to 2012,finds that inflation has a greater effect on labour productivity than do real wages. This absence of a link between productivity and real wage is largely due to lower bargaining power and structural problems, including high unemployment, a huge tax burden on wages and the large share of the informal sector in the Turkish manufacturing sector. Researchers (Lawrence et al. 2015) explain the sluggish rise in real wages over the long run (1970-2000) in US economy, may lie not with something that weakened labor's bargaining power but instead in changes in the relative prices of the goods and services that workers consume and those that they produce.

Positive relationship between labor productivity and worker compensation has puzzled the economists for a long time. On the one hand, some senior economists reckon that compensation stagnates or does not rise properly while productivity grows swiftly in many industries of the U.S. This may be due to the fall in bargaining power of workers as supply for labor exceeds demand. On the other hand, other economists argue that if fundamental factors like appropriate price deflator is taken into account when exploring trends for productivity 
enhancements and compensation rises, the line of growth for both should be identical, specifically, increases in compensation need to follow growth in productivity at the national level. This implies that workers benefit from productivity growth at the aggregate level. This paper analyzes the dynamics of productivity gains and compensation rises by discussing various theoretical relationships.

Applying the data from the U.S government agency, the Bureau of Labor Statistics, an empirical analysis was conducted in order to investigate the effects of productivity growth and other influential factors on annual compensation per worker. The paper points out there is a gap between productivity and compensation growth rates since the increase in compensation does not keep up with the rise in productivity. This can be due to the fall in the bargaining power of workers in the US as stated by Greenhouse and Leonhardt (2006). Cashell (2004) suggests that the gap between productivity and compensation growth could also be affected by changes in the competitiveness of labor market. The investigation found that industries with higher rate of unionization had relatively small gaps between productivity and compensation growth compared to the industries experiencing relatively larger declines in power of unionization. According to another research paper by Fleck et al, (2011) under the Bureau of Labor Statistics (BLS) in the U.S., there are two main components that account for the importance and direction of the compensationproductivity relationship. They are the difference between the price indices for inflation in the BLS hourly compensation and productivity measures (Consumer Price Index and Implicit Price Deflator containing different baskets of goods and services). If consumer price rises faster than output prices, purchasing power decreases and the compensationproductivity gap increases. The second is the share of output, "labor share", accounted for by workers' compensation. Labor share is a measure of how much of the economic pie goes to all employees.

When the share of output is constant or rising, employees benefit from the economic growth. When it falls, the gap between productivity and labour compensation widens. Since the 1970s, the rise in inflation-adjusted or real hourly compensation has lagged behind the increase in labor productivity. Furthermore, Lawrence and Gee (2012) mention that the average real hourly wage in the United States has been basically stagnant between 1973 and 2011 whereas labor productivity increased by 80 per cent leading to wage and labour productivity gap. On the other hand, Feldstein (2008) notes that the level of productivity doubled in the U.S. non-farm business sector between 1976 and 2006. Total compensation per hour rose at approximately the same rate per year during that period if nominal compensation is adjusted for inflation in the same rate as the nominal output amount that is used to compute productivity.

Apart from USA, other analytical studies have also been carried out in other countries especially in the developing ones. An empirical study (Tamasauskiene and Stankaityte, 2013) conducted in Lithuania by regions and different sectors shows that regional disparities of labour productivity are greater than wages. The correlation coefficient between wages and labour productivity analysed by regions and economic activities in 2005-10, observes that dissimilarities of wages were higher than labour productivity when analysed by regions and economic activities. Another study based on Malaysian economy (Goh and Wong; 2010) shows that there exists a long-run equilibrium relationship between real wages and productivity from 1970 to 2005, despite the fact that unemployment appears to be dichotomized from this equilibrium relationship. Although labor productivity is an important long-run factor in determining real wages, the productivity elasticity of real wages is greater than 1 (i.e. real wages are very responsive to a change in labor productivity), signaling the labor productivity gains lag behind the increase in real wages. An empirical study based on Tanzania (Islam, Kinyando and Nganga, 2015) finds no clear relationship between real wages and labour productivity by industry and sectors (public and private), though real wages have significant impact on productivity in the manufacturing sector, thus lending support to the efficiency wage hypothesis.

\section{Works in India}

An attempt (Upender, 1996) is made to estimate elasticity of labour productivity in the manufacturing sector in India so as to find out substitution possibilities of labour for capital in Indian manufacturing sector covering the period 1973-74 to 1989-90. The study finds that Indian manufacturing 
sector is capital intensive and is working under decreasing returns to scale. The elasticity of labour productivity is found to be significantly more than 1, implying the substitution possibilities in favour of labour is quite high.

While investigating the long-run relationship between labour productivity and employment, and between labour productivity and real wages in the case of the Indian manufacturing sector for the period 1973-1974 to 1999-2001, researchers (Bhattacharya, Paresh K., Popp and Rath, 2009) find that both employment and real wages exert a positive effect on labour productivity and argue that flexible labour market has a significant influence on productivity, employment and real wages in the case of Indian manufacturing.

Pointing out disparity between wage rates of directly employed and temporary workers in manufacturing sector in India, a study (Murti, Paul and Muralidharan, 2014) finds out, during the period 1998-99 to 2010-11, the growth in nominal wages appears to have been crowded out by a consistent increase in the consumer price index for industrial workers, rendering a scenario of temporary stagnant real wages in the manufacturing sector. Moreover, trend growth rates of wages of supervisory and managerial staff, notwithstanding variation across industries, are significantly higher than that of workers, indicating that the stagnation of the real wage is presumably a stylised fact for workers but not for managerial and supervisory staff. Another study (Das, Sengupta, 2015) examines the regional variation in output, employment and productivity growth with data from registered manufacturing industries across major states in India. It is observed that higher rate of growth of manufacturing output leads to higher rate of productivity growth, but not a faster rate of employment growth. The structural change took place in favour of capital that increased profit rate by displacing workers in manufacturing industries in India. This study reflects significant regional disparity in industrial growth in India although the incidence of unevenness declines at a very slow rate.

From the survey of selected literature at both aggregated and disaggregated levels, we find a vast number of literatures at both national and international levels, analyzing the relationship between real wage rate and labour productivity in the manufacturing sector in various countries including Indian manufacturing sector. It is quite clear that most of the studies lay stress mainly on the relationship between labour productivity and real wage rate. However, none of these studies have examined the role of wage share in value added ratio, representing the bargaining power of the workforce and labour's terms of trade reflecting the changes in the prices of relative consumption goods and output, on real wage rate in Indian manufacturing sector and judge their relative importance along with labour productivity variable. In this context, the study concentrates in examining the relationship between the real wage rate and labour productivity, wage share in value added ratio and labour's terms of trade in Indian manufacturing sector during the period 1991-2010 i.e., the post reform period. With this purpose the study divides the manufacturing sector into three use-based broad groups (Consumer, Intermediate and Investment goods sectors) and also attempts to analyse the role of these determinants for real wage rate in these groups along with the aggregate manufacturing sector.

\section{DATA AND SOURCES}

The relation between productivity and wages has been explored using standard microeconomic theory of wage determination. We use real wages, defined as nominal emolument per worker divided by Consumer Price Index (CPI) deflator. We use average productivity, derived by dividing value of output by manufacturing price deflators per worker to measure labour productivity. The cost of living is taken as the cost of living index of urban industrial workers in India during the period under investigation. The time series data of the principal characteristics of major industry groups as well as for the manufacturing sector as a whole, where industries are classified according to National Industrial Classification (NIC) obtained from Annual Survey of Industries (ASI) during the post reform years, starting from 1991-92 to 2010-11. The ASI provides estimates of value added, wages to workers, number of workers, fixed capital, total input etc. for organized or the registered sector of manufacturing in India.

The manufacturing sector has been divided into three use based sectors, i.e. investment goods, 
intermediate goods and consumer goods for the purpose of our study. This use-based classification is carried out using a detailed weighting diagram provided by Central Statistical Organization (CSO). Data are needed for the industry groups at two, three, four and more digit levels of disaggregation in order to classify them into three used based sectors. The use based classification is described below:

\section{Consumer Goods Sector}

Food except beverage

Beverage

Tobacco

Textile

Footwear and other wearing apparels

Printing and Publishing

Furniture and Fixture

Miscellaneous

\section{Intermediate Goods}

Wood and Cork

Paper and Paper product

Leather and fur product

Rubber product

Chemical and Chemical product

Petroleum and Coal product

Non-metallic Mineral product

Basic Metal product

Metal product

Gas and Electricity

\section{Investment Goods}

Transport

Electrical Machinery

Non-electrical Machinery

\section{METHODOLOGY}

The main purpose of our study is to find out the relationship between real wage rate and labour productivity in Indian manufacturing sector as a whole during the post reform years (19912010) as well as in the three use-based sectors namely consumer goods, Intermediate goods and Investment Goods as already described. A simple micro-economic model is constructed and theoretical links between labour productivity and real wages are illustrated by forming an accounting identity relating consumption wages to labour productivity and by extension to product wages.

$$
\frac{W}{C P I \times L}=\frac{V A}{P V A \times L} \times \frac{W}{V A} \times \frac{P V A}{C P I}
$$

Where, $\mathrm{CPI}=$ Consumer price index

$\mathrm{VA}=$ gross value added

$\mathrm{W}=$ nominal labour compensation

$\mathrm{L}=$ number of workers

PVA $=$ prices of value added (GDP deflator)

In the above equation,

$$
\begin{aligned}
& \frac{W}{C P I \times L}=\text { real wage rate } \\
& \frac{V A}{P V A \times L}=\text { labour productivity (Lp) } \\
& \frac{W}{V A}=\text { wage share in value added }
\end{aligned}
$$

and $\frac{P V A}{C P I}=$ labour's terms of trade

Therefore equation (1) can be written as,

$$
\hat{W}=L p+W / V A+P V A / C P I
$$

Taking logarithm of both sides we have,

$$
\log \hat{W}=\log L p+\log W / V A+\log P V A / C P I \ldots
$$

The relation becomes simpler after taking time derivatives of equation (2)

$$
\Delta \hat{W}=\Delta L p+\Delta W / V A+\Delta P V A / C P I
$$

Equation (3) explains the relationship between real wage rate and labour productivity, which shows that real wage rate is positively related with productivity of labour. Higher the real wage higher will be the productivity of workers and vice-versa. According to the above equation, rate of growth of real wage rate depends on other two factors namely the wage share in value added ratio and labour's terms of trade.

Labour's terms of trade are a measure of how shifts in the relative consumption goods and output affect the consumption wage of workers. Improving terms 
of prices of trade means that the goods that workers produce are increasing in price more rapidly than the goods that the workers consume. All else being equal, improvements in labour's terms of trade are good for workers, because they result in higher real wages for workers as evident from equation (3). On the other hand, wage share in value added ratio reflects the bargaining power of the working class. Lower the wage share, lower the bargaining power of the workers indicating tilt of power in favour of the capitalists and increasing inequality in the economy as a whole.

\section{RESULTS AND ANALYSIS}

The present study wants to find out the relationship between real wage rate and labour productivity, wage share in value added ratio and labours' terms of trade in the registered manufacturing sector in India during the post reform years, i.e., 1991-2010. With this purpose the study (see Table 1) estimates the likely trends of the above variables in these two decades. According to our study the real wage rate in Indian manufacturing sector (Fig. A.1 in Appendix) becomes stagnant during this twenty year study period. It is obvious from Table 1 that the wage rate shows no significant movement in the three use based sectors as well as the total manufacturing sector in India. Keeping the distribution of wealth in mind, the study reveals that while the annual rate of profit in the three use based sectors as well as the manufacturing sector as a whole remains almost stable during the study period (the rate of change in profit rate is statistically insignificant), the wage share in value added ratio shows significant downward movement in both intermediate and investment goods sector. But the rate of decline in the wage share is not so significant in the consumer goods sector in India during these 20 years. In the manufacturing sector as a whole, the wage share in value added ratio declines at the rate of 4.3 per cent (statistically significant at 5\% level) per annum signifying the declining bargaining power of the labour force in India.

It is clear from the Table 1 that labour productivity has increased significantly in all the three use based sectors as well as the aggregate manufacturing sector during our period of investigation. On the other hand, the labour's terms of trade (PVA/CPI ratio) follows significant downward movement during the same years. Though it is at best a minor contributor to the ongoing puzzle about the increasing divergence between real wage rate and labour productivity, it is still interesting to see how these two price indices have evolved over time. According to our analysis, declining terms of trade for labour reduces purchasing power countering whatever gains were generated by rising labour productivity. So it is evident from Table 1, that the increase in labour productivity ratio is countered by declining wage share in value added as well as decreasing terms of trade for labour in the manufacturing sector in India in all the three broad based sectors, resulting stagnant real wage rate in Indian manufacturing sector during our period of study.

Following our line of study we have also attempted to find out the role of technical composition of capital or capital intensity of production in determining the real wage rate as in the long run both labour and capital are variable. It is found out that technical composition of capital shows sharp rising trend in all the three use based sectors in India as well as the total manufacturing sector during the study period explaining the rising labour productivity in Indian manufacturing sector. The increasing technical composition of capital reflects that labour is gradually replaced in almost all the manufacturing sectors in India by capital in the post

Table 1: The Rate of Growth of Real Wage Rate and Related variables

\begin{tabular}{ccccccc}
\hline & $\mathbf{P} \%$ & W/VA & Lp & Tc & $\hat{\mathbf{w}}$ & PVA/CPI \\
\hline Consumer Gooods & $-1.0(-.73308)$ & $-2.291(-1.95058)$ & $3.7013(3.456986)^{*}$ & $3.3913(12.81768)^{*}$ & $-.1(-.2078)$ & $-.013(-7.838)^{*}$ \\
Intermediate goods & $-.7(-1.719)$ & $-4.4(-9.149)^{*}$ & $3.3(8.099)^{*}$ & $1.9(9.132)^{*}$ & $-.4(-1.449)$ & $.008(2.935)^{*}$ \\
Investment goods & $-.9(-2.58)$ & $-4.2(-12.443)^{*}$ & $6.4(25.005)^{*}$ & $1.7(6.419)^{*}$ & $0.00(.255)$ & $-.024(-11.960)^{*}$ \\
All & $\mathbf{0 . 1 ( 0 . 2 9 5 )}$ & $-\mathbf{- 4 . 3 ( - 1 1 . 0 8 2})^{*}$ & $\mathbf{5 . 5 ( 2 0 . 8 9 4 ) ^ { * }}$ & $\mathbf{4 . 6 ( 2 3 . 5 3 7 ) ^ { * }}$ & $\mathbf{- 0 . 2 ( - . 4 9 6 )}$ & $\mathbf{- 1 . 5 ( - 8 . 2 3 1 ) ^ { * }}$ \\
\hline
\end{tabular}

t values are in parantheses; ${ }^{*}$ t values are significant at $5 \%$ level. 
Table 2: Correlation Coefficient between real wage rate and related variables

\begin{tabular}{cccccc}
\hline Sector & Lp and $\hat{\mathbf{W}}$ & Lp and Tc & Tc and $\hat{\mathbf{W}}$ & W/VA and $\hat{\mathbf{W}}$ & CPI/PVA and $\hat{\mathbf{W}}$ \\
\hline Consumer & -0.126045 & 0.466397 & -0.088068 & 0.411119 & -0.117549 \\
Goods & $(\mathrm{p}=0.596581)$ & $(\mathrm{p}=0.038227)^{*}$ & $(\mathrm{p}=0.712184)$ & $(\mathrm{p}=0.071736)^{* *}$ & $(\mathrm{p}=0.621761)$ \\
Intermediate & -0.168325 & 0.806517 & 0.0036858 & 0.438165 & 0.353173 \\
Goods & $(\mathrm{p}=0.478946)$ & $(\mathrm{p}=1.7 \mathrm{E}-05)^{*}$ & $(\mathrm{p}=0.987715)$ & $(\mathrm{p}=0.053293)^{* *}$ & $(\mathrm{p}=0.126617)$ \\
Investment & 0.0160757 & 0.955587 & 0.150976 & -0.086053 & -0.039199 \\
Goods & $(\mathrm{p}=0.946288)$ & $(\mathrm{p}=0 . \mathrm{p}<0.00001)^{*}$ & $(\mathrm{p}=0.525205)$ & $(\mathrm{p}=0.718467)$ & $(\mathrm{p}=0.8697)$ \\
All & $\mathbf{- 0 . 1 5 4 2 8 9}$ & $\mathbf{0 . 9 7 3 9 8 2}$ & $\mathbf{0 . 2 1 4 6 1 2}$ & $\mathbf{0 . 3 3 2 2 4 4}$ & $\mathbf{- 0 . 2 9 2 5 9 3}$ \\
& $(\mathrm{p}=\mathbf{0 . 5 1 6 8 2 4})$ & $(\mathrm{p}<\mathbf{0 . 0 0 0 0 1})^{*}$ & $(\mathrm{p}=\mathbf{0 . 3 6 3 5 7 5})$ & $(\mathrm{p}=\mathbf{0 . 1 5 2 4 3 )}$ & $(\mathrm{p}=\mathbf{0 . 2 1 0 6 0 3})$ \\
\hline
\end{tabular}

${ }^{*}$ The result is significant at $p<0.05 ;{ }^{* *}$ The result is significant at $p<0.10$.

reform years. The replacement of labour by capital may be forwarded as another reason for declining wage share in value added ratio for the Indian manufacturing sector during this period. This may cause a decrease in the demand for labour in the manufacturing sector in India resulting stagnant real wage rate. The above analysis also shows that in the manufacturing sector in India the rate of growth of labour productivity over compensates the increase in technological composition of capital. But higher labour productivity in the registered manufacturing sector is not associated with higher real wage signifying the exploitation of workers in the hands of the employers.

To find out the relative contributions of all the above mentioned variables in determining the real wage rate in manufacturing sector in India at both aggregated and disaggregated levels, we have determined the correlation coefficients between real wage rate and all these variables during the study period, Table 2 .

From Table 2, it is evident that none of the above factors except wage share in value added ratio have significant correlation with the real wage rate. The correlation coefficient between wage share in value added ratio and real wage rate is quite high and significant for consumer goods and intermediate goods sector in India though for the aggregate manufacturing sector the correlation coefficient between real wage rate and wage share ratio is found to be moderate. The correlation coefficient between labour productivity and technical composition of capital is found to be quite high in manufacturing sector in India during 1991-2010 at both aggregated and disaggregated levels. This may explain the fact that higher labour productivity in Indian manufacturing sector during the post reform years is mainly due to the increasing technological composition of capital over these years.

So it is observed that wage share in value added ratio emerges to be the most important determining force in the movement of the real wage rate in the organized manufacturing sector in India at both aggregated and disaggregated levels during the study period.

\section{Contractualisation of labour force in India}

The preceding section outlines some important facts in India's manufacturing sector pertaining to labour productivity and the distribution of income and wages.

Table 3: Percentage distribution of Employment in different Manufacturing Sectors in India, 2010

\begin{tabular}{cc}
\hline Name of the Manufacturing sector & $\begin{array}{c}\text { Percentage of } \\
\text { Employment }\end{array}$ \\
\hline Food, Beverage and Tobacco & 17.1 \\
Textile, Leather, Wearing Apparel & 21.6 \\
Chemical and Pharmaceutical products & 9 \\
Metal and Metal products & 13.5 \\
Computer and electrical equipments & 6.4 \\
Machine and equipments and Motor & 13.3 \\
vehicles and Transport & 19.1 \\
Other manufacturing & \\
\hline
\end{tabular}

However, these changes cannot be attributable to increases in the capital intensity of production alone. There may have been other changes in the labour market during this period which can explain these trends. One such fact is that in India, nearly 40 per cent of organized manufacturing sector employees are in low-paying food, beverage and tobacco and the textiles, leather and apparel industries (see Table 3) which results in declining wage 
share in value added ratio as well as stagnant real wage rate. Another critical factor is the increased contractual workforce in manufacturing sector in India. Production workers in India's manufacturing sector are divided into two categories - permanent and contract workers. The latter are hired via contractors, can be hired and fired at the will of the owners of firms and receive wages which are much less than those of permanent workers. Employment in India's organized manufacturing sector reflects that whereas employment of nonproduction and directly employed production workers has been growing since 2004, but not nearly as rapid as production workers employed through contractors which can be regarded as one of the main underlying reasons for the falling wage share and nearly stagnant real wage rate in the organized manufacturing sector during the observation period. According to Table 4, where the year 1999 is taken as base year $(=100)$, the last two decades witnessed a sharp increase in the share of contract workers at the expense of regular employment in the organized manufacturing sector in India.

Table 4: Employment in India's organized manufacturing Sector, 1995-2010

\begin{tabular}{cccc}
\hline Year & $\begin{array}{c}\text { All } \\
\text { Employees }\end{array}$ & $\begin{array}{c}\text { Directly } \\
\text { Employed }\end{array}$ & $\begin{array}{c}\text { Contract } \\
\text { Workers }\end{array}$ \\
\hline 1995 & 113 & 122 & 76 \\
1996 & 105 & 109 & 89 \\
1997 & 105 & 109 & 86 \\
1998 & 99.6 & 105 & 79 \\
1999 & 100 & 100 & 100 \\
2000 & 96 & 91 & 96 \\
2001 & 94 & 92 & 109 \\
2002 & 95 & 92 & 118 \\
2003 & 95 & 91 & 126 \\
2004 & 99 & 93 & 144 \\
2005 & 107 & 98 & 168 \\
2006 & 117 & 105 & 195 \\
2007 & 124 & 110 & 214 \\
2008 & 133 & 115 & 234 \\
2009 & 140 & 120 & 252 \\
2010 & 150 & 126 & 280 \\
\hline
\end{tabular}

Index $1999=100$.

Source: US Bureau of Labour Statistics, International Labour Comparisons.
The share of contract workers in total employment for production workers, in the organized manufacturing sector rose from 13.5 per cent in 1990-91 to 34 per cent in 2010-11, while that of directly employed workers fell from 86.5 per cent to 66 per cent in the same period (Fig 1).

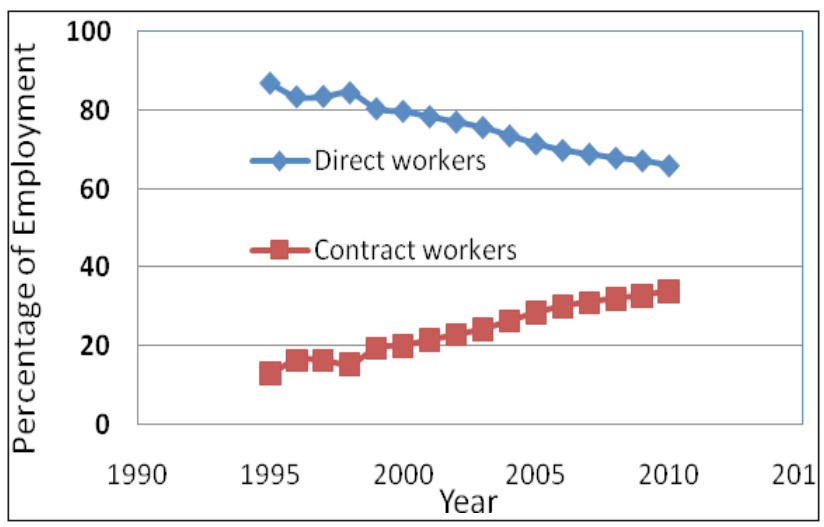

Fig. 1: Percentage distribution of Direct and Contract workers in Organized Manufacturing sector in India

It is evident from Table A.1 in Appendix, that number of contract workers has been increased from 0.9047 million in 1995 to 3.09 million in 2010. On the other hand, employment of direct workers involved in production in the organized manufacturing sector remained almost unchanged at 5.97 million during these two decades. Two reasons can be attributed to this increasing informalization of employment in organized manufacturing sector in India. First, the use of contract workers provides a means of getting around stringent labour regulations, particularly the Industrial Disputes Act, as contract workers do not come under the purview of labour laws that are applicable to directly employed workers in labour markets.

Secondly, contract workers are significantly cheaper, performing the same task as permanent workers and thus lowering the average wages for production workers. Furthermore, their presence in the workforce helps the firms' management diminish the bargaining power of regular workers and exert downward pressure on their wages. In this way increasing contract workforce lowers the wage bill and improves profitability for the firms. Thus, contractualisation of the workforce though not an implication of the rising capital intensity of production, may well have affected the changes in the distribution of income and wage inequality. 
Table 5: Wage Rate Differentials in Organized Manufacturing Sector

\begin{tabular}{cccc}
\hline Year & $\begin{array}{c}\text { Direct } \\
\text { Workers }\end{array}$ & $\begin{array}{c}\text { Contract } \\
\text { Workers }\end{array}$ & $\begin{array}{c}\text { Contract worker's wage } \\
\text { as a proportion of } \\
\text { direct worker (in \%) }\end{array}$ \\
\hline $2001-02$ & 164 & 90 & 54.87 \\
$2005-06$ & 198 & 116 & 58.59 \\
$2010-11$ & 313 & 221 & 70.61 \\
\hline
\end{tabular}

Source: Annual Survey of Industries, Various Issues and Author's own calculations

This may contribute to rising wage inequality between direct workers and the contractual workers. Table 5 reveals that wage differentials between direct and contract production workers in organized manufacturing sector in India during our period of investigation. It is well established from the above table that wage differential is rising sharply between direct and contract workers in organized manufacturing sector over these years thus exhibiting falling wage share in value added ratio and stagnant average real wage rate.

\section{CONCLUSION}

The empirical analysis reveals that in the organized manufacturing industry as a whole as well as the three use based sectors in India the declining wage share neutralizes the effect of increasing labour productivity. On the other hand, the falling Labour's terms of trade means that the goods that workers produce are decreasing in price more rapidly than the goods that the workers consume which has significant negative influence on the movement of the real wage rate as is evident from our analysis. All these factors result in almost stagnant wage rate growth in the organized manufacturing sector in India during the study period. Again the correlation result fails to ascertain any significant relationship between labour productivity and real wage rate. This absence of a link between productivity and real wage may be largely due to lower bargaining power and structural problems, including high unemployment, low wages and the presence of large number of contract workforce in the organized manufacturing sector in India.

The declining wage share in value added in the manufacturing sector in India at both aggregated and disaggregated level points out the tilt of power in favour of the capitalists indicating that the bargaining power of the working class has not been strong enough in raising the wage share. Therefore the working class movement in Indian manufacturing sector is not successful in raising the wage share in the manufacturing sector as is evident from the study. Hence the result is in contradiction with the argument forwarded by the proponents of Rising Strength of Labour Theory (Boddy and Crotty, 1975; Glyn and Suitcliffe, 1972; Weisskopf, 1979), which states that the process of accumulation tends to alter the balance of politicaleconomic power between labour and capital, in such a way as to enable the working class to increase the wage share in national income. But the rising number of contractual workers in comparison with directly employed workers in Indian manufacturing sector exhibits the inability of the working class to bargain successfully for higher wage share. This can be attributed to the fact that contract workers are significantly cheaper, performing the same task as permanent workers and thus lowering the average wages for production workers. Furthermore, their presence in the workforce helps the firms' management diminish the bargaining power of regular workers and exert downward pressure on their wages. In this way increasing contract workforce lowers the wage bill and improves profitability for the firms. Thus, contractualisation of the workforce though not an implication of the rising capital intensity of production, may well have affected the changes in the distribution of income and wage inequality.

By going through the evolution of wage policy in India, a proper understanding of the wageproductivity-price relationship is essential to reverse the low productivity growth, stagnant real wage rate and rising unemployment in the country. More emphasis should be given on the working of various wage setting institutions like wage boards, labour courts, industrial tribunals and processes of collective bargaining with guidelines on the part of the government for permissible non-inflationary wage increases. Minimum wage levels need to be adjusted from time to time to take into account changes in the cost of living and other economic conditions. Failure to do so may lead to a decline of the purchasing power of the workers with lower wage rates when prices of goods and services are rising, or to greater wage inequality when the 
general level of wages is increasing. As far as the contract workers are concerned, it is observed that collusive agreements between various agents often result in the exploitation of contract labour. It is necessary to curb the exploitation of this vulnerable section of the workforce by fixing the terms of contract through different labour reform measures. The reformed laws must suit emergent conditions and must provide more flexibility to employers. Above all, they must ensure fair treatment of workers, and provide a wider social safety net. Thus, to bring back the economy to a stable growth path, efficient policy efforts are necessary to link productivity with real wage growth.

\section{APPENDIX}

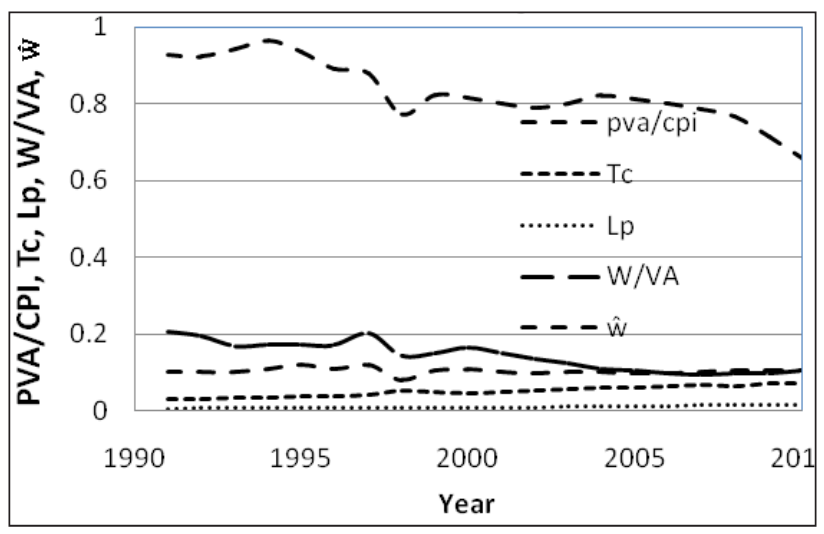

Fig. A.1: Movement of Labour productivity and other related variables in Organized manufacturing sector in India

Table A.1: Number of direct and Contract workers in Indian Manufacturing Sector (in Million)

\begin{tabular}{ccc}
\hline Year & Direct & Contract \\
\hline 1995 & 5.967333 & 0.904715 \\
1996 & 5.325866 & 1.05887 \\
1997 & 5.337328 & 1.055405 \\
1998 & 5.106673 & 0.940562 \\
1999 & 4.878188 & 1.191596 \\
2000 & 4.749073 & 1.208545 \\
2001 & 4.360417 & 1.203113 \\
2002 & 4.360417 & 1.302453 \\
2003 & 4.313021 & 1.390755 \\
2004 & 4.407813 & 1.589434 \\
2005 & 4.644792 & 1.85434 \\
2006 & 4.976563 & 2.152358 \\
2007 & 5.213542 & 2.362075 \\
2008 & 5.450521 & 2.58283 \\
2009 & 5.6875 & 2.781509 \\
2010 & 5.971875 & 3.090566 \\
\hline
\end{tabular}

Source: US Bureau of Labour Statistics.

\section{REFERENCES}

Bhattyacharya, M., Narayan, P.K., Popp, S. and Badri, N.R. 2011. 'The productivity-wage and productivityemployment nexus: A panel data analysis of Indian manufacturing', Empirical Economics, 40(2): 285-303.

Boddy, R. and Crotty, J. 1975. 'Class Conflict and Macro-Policy: The Political Business Cycle', Review of Radical Political Economics, 7(1): 1-19.

Cashell, B.W. 2004. 'Productivity and Wages', Congressional Research Service, Federal Publications, ILR School, Cornell university.

Das, P. and Sengupta, A. 2015. 'Wages, productivity and employment in Indian manufacturing industry 19982010,' The Journal of Industrial Statistics, 4(2): 208-220.

Feldstein, M.S. 2008. 'Did Wages Reflect Growth in Productivity?' NBER Working Paper No. 13953, JEL No. E24, J3.

Fleck, S., Glaser, J. and Sprague, S. 2011. 'The compensationproductivity gap: A visual essay', Monthly Labour Review, 134(1): 57-69.

Glyn, A. and Suitcliffe, B. 1972. 'British Capitalism, Workers and the Profit Squeeze' Penguin Publishers.

Goh, S.K. and Wong, K.N. 2010. 'Analyzing the productivitywage-unemployment nexus in Malaysia: Evidence from the macro-economic perspective', Discussion paper, 12/10, ISSN 1441-5429, Monash University.

Greenhouse, S. and Leonhardt, D. 2006. 'Real Wages Fail to Match a Rise in Productivity', The New York Times.

Islam, R., Kinyaondo, A. and Nganga, J. 2015. 'Real wages and labour productivity in Tanzania', Journal of African studies and Development, 7(3): 81-98.

Lawrence, M. and Kar-Fai Gee, 2012. 'Why Aren't Workers Benefiting from Labour Productivity Growth in the United States?', International Productivity Monitor; Ottawa, 23: 31-43.

Murti, A.B., Paul, B.G.D and Muralidharan, T. 2014. 'Should real wages of workers go up in Indian manufacturing?, Economic and Political Weekly, 49(30).

Nikulin, D. 2015. "Relationship between wages, Labour Relationship between wages, labour productivity and unemployment rate in new EU member countries" Journal of International Studies, 8(1): 31-40

Sharpe, A., Arsenault, J.F. and Harrison P. 2008. The Relationship between Labour Productivity and Real Wage Growth in Canada and OECD countries, CSLS Research Report No. 2008-8. 
Tamašauskiene, Z. and Stankaityte, A. 2013. 'Evaluating of the Relationship between Wages and Labour Productivity in Lithuania: Territorial and Sectoral Approaches', Socialiniai Tyrimai /Social Research, 1(30): 24-35.

Upender, M. 1996. 'Elasticity of Labour productivity in
Indian Manufacturing', Economic and Political Weekly, 31(21): M7-M10.

Weisskopf, T.E. 1979. 'Marxian crisis theory and the rate of profit in the postwar U.S. economy', Cambridge Journal of Economics, 3(4): 341-378.

Yildirim, Z. 2015. 'Relationship among labour productivity, real wages and inflation in Turky', Journal of Economic Research, 28(1): 85-103. 
